\title{
A comparative analysis of phytoplankton diversity and abundance during monsoon season in selected beels (wetlands) of Assam, India
}

\author{
Jeetendra Kumar ${ }^{\text {* }}$, A. K. Yadav ${ }^{2}$ and B. K. Bhattacharjya ${ }^{2}$ \\ ${ }^{1}$ ICAR- Central Inland Fisheries Research Institute, Regional Centre, Allahabad- 700120 (Uttar Pradesh), INDIA \\ ${ }^{2}$ ICAR- Central Inland Fisheries Research Institute, Regional Centre, Guwahati- 781006 (Assam), INDIA \\ *Corresponding author. E-mail: jeetendrak142@gmail.com
}

Received: September 19, 2016; Revised received: June 19, 2017; Accepted: October 20, 2017

\begin{abstract}
Water collected from 8 selected floodplain wetlands (beels) of Brahmaputra valley basin were examined using both filtered method (FM) and sedimentation method (SM) for the assessment of phytoplankton diversity and abundance. A total 22 and 41 species were recorded by employing FM and SM, respectively. There was a significance difference $(p<0.05)$ between FM and SM. Species and abundance of phytoplankton were lesser in FM than $\mathrm{SM}$ and it was due to exclusion of minute size $(<25 \mu)$ from net and maximum retention of species in sedimentation method. Chlorophyta, Bacillariophyta, Cyanophyta, Euglenophyta, Chrysophyta and Dinophyta were recorded during study period. Chlorophyta, Bacillariophyta and Cyanophyta were dominant groups. Bacillariophyta was dominant group followed by Chlorophyta and Cyanophyta in FM while Chlorophyta was dominant group followed by Bacillariophyta and Cyanophyta SM. Total phytoplankton densities were recorded from 35 cells $\mathrm{L}^{-1}$ to 3808 cells $\mathrm{L}^{-1}$ in $\mathrm{FM}$ while $1.55 \times 10^{4}$ cells $L^{-1}$ to $12.33 \times 10^{5}$ cells $L^{-1}$ to in $S M$. Diversity indices of phytoplankton were varied widely in FM and SM. Siligurijan beel and Bildora beels were considered more stable environment than other beels based on diversity indices.
\end{abstract}

Keywords: Beels, Diversity indices, Filtered method, Phytoplankton, Sedimentation method

\section{INTRODUCTION}

India has extensive wetlands mainly associated with the Ganga and Brahmaputra rivers systems, which are collectively termed as floodplain wetlands. These include abandoned river channels (ox- bow lakes), tectonic depressions, sloughs, meander scroll depressions and so on, which are either connected to their parent/ adjacent rivers or receive floodwaters and/or surface runoff from their catchments. These wetlands are locally known as beel in Assam, India. Assam has more than 100,000 hectare constituting $49.45 \%$ water bodies of the state. Beel fisheries are an important component of the fisheries of Assam (Chandra, 2011). Phytoplankton play a vital role in the biological productivity of aquatic ecosystems including beels. Since, they form the base of the ecological pyramid as a major component of primary producers. These unicellular organisms have chlorophyll and release oxygen $\left(\mathrm{O}_{2}\right)$ by immobilizing carbon dioxide $\left(\mathrm{CO}_{2}\right)$ during photosynthesis and are responsible for at least half of the global primary productivity. Most of the aquatic organisms including fishes thrive on phytoplankton for their growth and energy requirements either directly or indirectly and thus constitute an important component of the food web. Diversity of phytoplankton and biological productivity of an aquatic ecosystem is greatly influenced by hydrological regimes during the southwest monsoon season (June to September) in India (Madhu et al., 2017). The Northeast region (NER) in India is amongst the highest rainfall regions of the world (Rajeevan et al., 2006). Studies on diversity of phytoplankton from the beels of Assam are limited and fragmented (Goswami and Goswami, 2001; Sharma, 2004, 2012, 2015; Bhuyan et al., 2009). This study was aimed to differentiate between filtered and sedimentation methods for assessment of phytoplankton diversity and abundance in selected wetlands in Assam, India.

\section{MATERIALS AND METHODS}

The present study was conducted during June 2015 to August 2015 (three months) in Mer beel (Nagaon district), Bildora beel, Deepor beel, Siligurijan beels (Kamrup district) Charan beel, 46 Morakolong beel, Jaluguti beel, and Kachodhara beels (Morigaon district) of Brahmaputra valley, Assam, India. From each wetland, 3 samples each for both FM and SM were collected at three different locations for phytoplankton analysis. The details of the selected wetlands have been given in Table1.

Two methods had been followed for phytoplankton sample collection viz; filtered method and sedimentation method respectively. For filtered method, we filtered 50 litre water through a phytoplankton filtered (mesh size $25 \mu$ ) at three different locations and col- 
lected the filtered samples in $100 \mathrm{ml}$ plastic bottles and preserved them with $0.2 \mathrm{ml}$ Lugol's solution. For sedimentation method, we collected $1000 \mathrm{ml}$ water sample in plastic bottles at three different locations and preserved them with 2-3 ml Lugol's solution. The samples were stored in ice box in the field for their transportation to the laboratory. The samples of plastic bottles were placed in a $1000 \mathrm{ml}$ measuring cylinder for settle the phytoplankton and stored in dark at low temperature for 24- 48 hour. A siphoning procedure was followed to obtain $50 \mathrm{ml}$ concentrates.

One $\mathrm{ml}$ of the concentrated sample was examined microscopically under an electronic microscope of $400 \mathrm{X}$ magnification in a Sedgwick-Rafter counting chamber. Chain-forming cells were counted on per cell basis and empty cells were excluded. Taxonomic criteria and diagnosis for phytoplankton identification were mainly based on Bellinger and Sigee (2010), Cox (1996) Dominance index, Richness index, Evenness index, Shannon index and Simpson index were widely used for estimation of diversity indices (Shashi Shekhar et al., 2008; Sultana and Gupta, 2009) . Past software was used to determine the various diversity indices for phytoplankton species (Park et al., 2008).

\section{RESULTS}

A total of 22 species from FM and 41 species from SM (Fig. 1) belonging to Green Algae (Chlorophyta), BGA (Cyanophyta), Diatoms (Bacillariophyta), Euglenoids (Euglenophyta), Golden-Brown Algae (Chrysophyta)

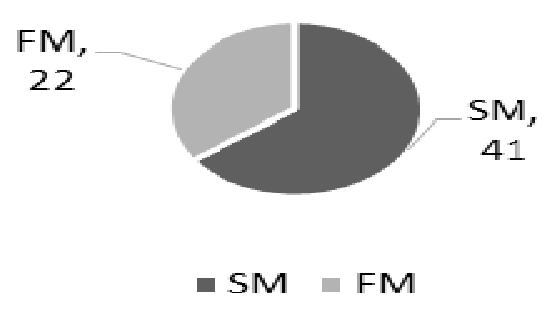

Fig. 1. Distribution of species number (in cell number) of phytoplankton by FM (22 Nos.) and SM (41 Nos.) in beels of Assam.

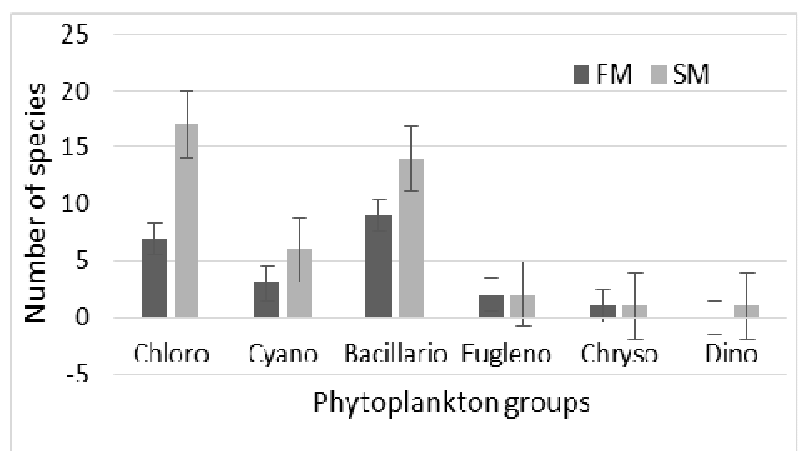

Fig. 2. Species (in numbers) recorded in different phytoplankton groups by FM and SM.
Table 1. Overview of the selected beels located at districts of Assam.

\begin{tabular}{|c|c|c|c|}
\hline Beels & $\begin{array}{l}\text { Location/ Re- } \\
\text { gions/ Areas }\end{array}$ & $\begin{array}{l}\text { Area } \\
\text { (ha) }\end{array}$ & Connectivity \\
\hline Mer & Nagaon & 19 & Closed \\
\hline Bildora & Kamrup & 35 & Seasonal open \\
\hline Deepor & Kamrup & 424 & Seasonal open \\
\hline Siligurijan & Kamrup & 9 & Seasonal open \\
\hline Charan & Morigaon & 60 & Seasonal open \\
\hline $\begin{array}{l}\text { 46Morako- } \\
\text { long }\end{array}$ & Morigaon & 78 & Seasonal open \\
\hline Jaluguti & Morigaon & 35 & Closed \\
\hline Kachodhara & Morigaon & 85 & Seasonal open \\
\hline
\end{tabular}

and Dinoflagellates (Dinophyta) were recorded during 3 months sampling period (Table 2). Bacillariophyta was dominant group followed by Chlorophyta and Cyanophyta in FM whereas Chlorophyta was dominant group followed by Bacillariophyta and Cyanophyta in SM (Fig. 2).

The number of species and abundance varied in different wetlands. Species numbers and phytoplankton densities were always lower in filtered method than sedimentation method (Fig. 2) and it was recorded less than 2 per cent of total density (Fig. 3). The species recorded from 2 to 10 by FM whereas 10 to 18 by SM respectively (Fig. 4). The lowest number of species was recorded in 46 Morakolong beel ( 2 species) by filtered method, whereas the highest number was recorded in Bildora beel (18 species) by sedimentation method. Total phytoplankton densities were recorded

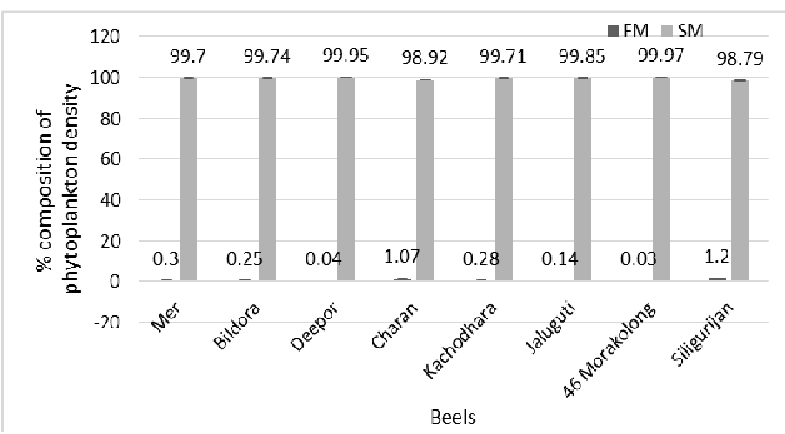

Fig. 3. Percentage contribution of phytoplankton in FM and SM in Beels of Assam.

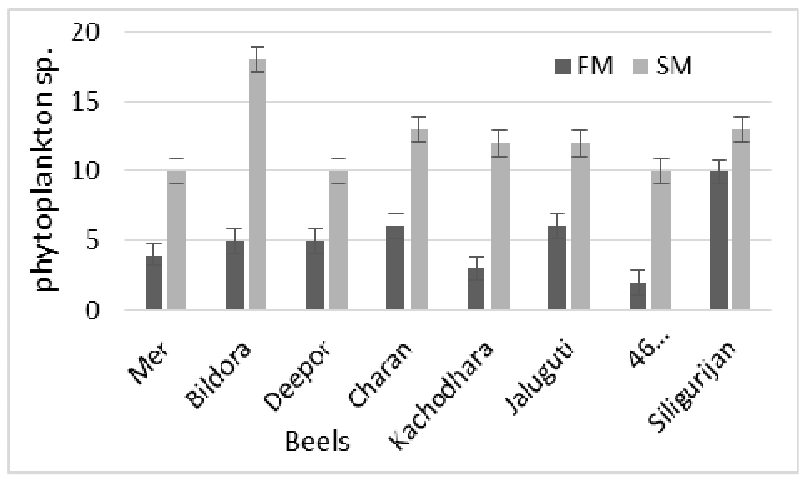

Fig. 4. Distribution of total phytoplankton species in different beels of Assam by FM and SM. 
Jeetendra Kumar et al. / J. Appl. \& Nat. Sci. 9 (4): 2285 - 2290 (2017)

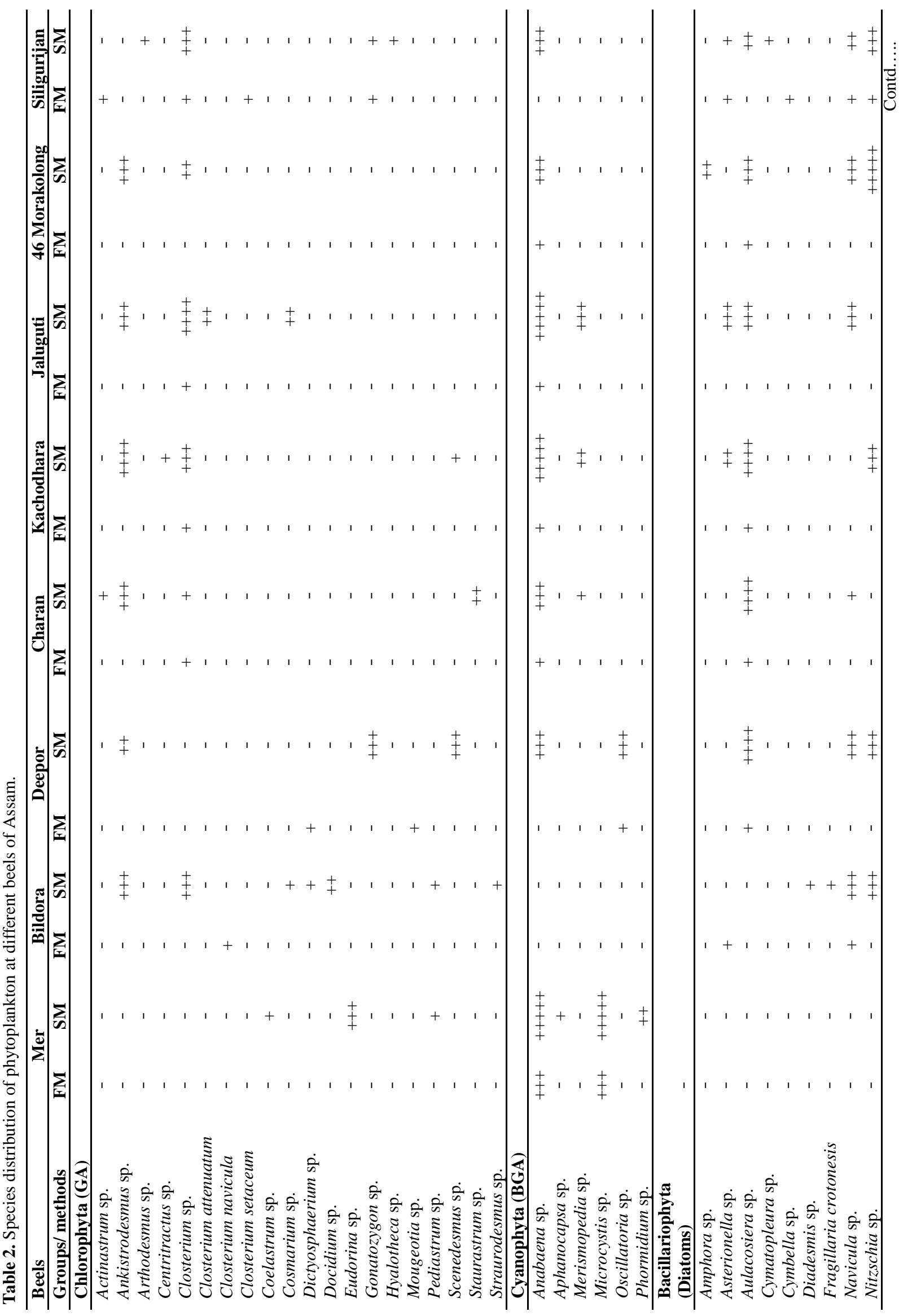


Jeetendra Kumar et al. / J. Appl. \& Nat. Sci. 9 (4): 2285 - 2290 (2017)
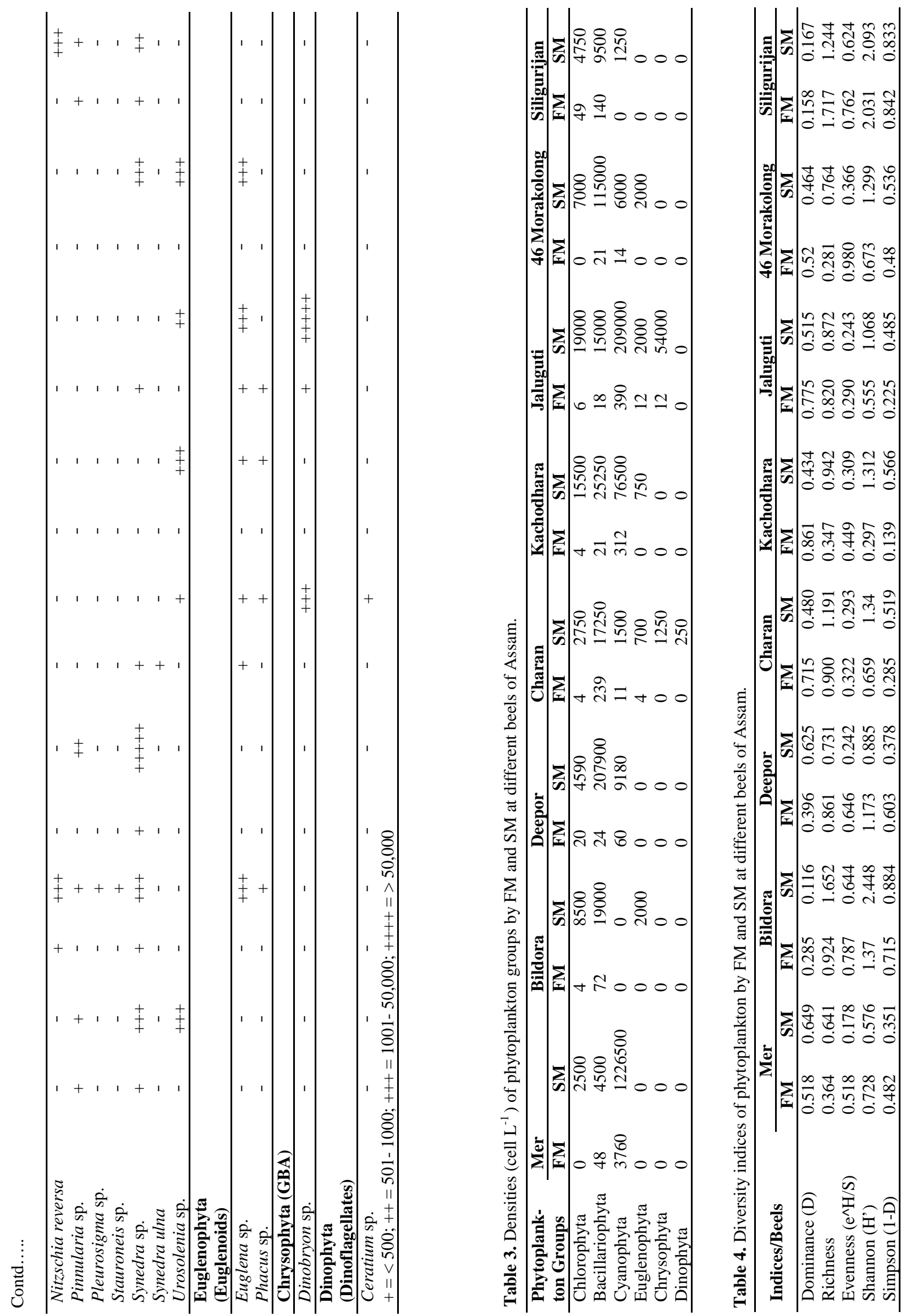
Table 5. Range of diversity indices of phytoplankton by FM and SM.

\begin{tabular}{lll}
\hline \multirow{2}{*}{ Diversity indices } & Filtered method & Sedimentation method \\
\cline { 2 - 3 } & Min to Max & Min to Max \\
\hline Dominance (D) & 0.158 (Siligurijan) to 0.861 (Kachadhara) & 0.116 (Bildora) to 0.649 (Mer) \\
Richness & 0.281 (46 Morakolong) to 1.717 (Siligurijan) & 0.642 (Mer) to 1.652 Bildora) \\
Evenness (e^H/S) & 0.290 (Jaluguti) to 0.980 (46 Morakolong) & 0.178 (Mer) to 0.642 (Bildora) \\
Shannon (H') & 0.297 (Kachadhara) to 2.031 (Siligirijan) & 0.576 (Mer) to 0.448 (Bildora) \\
Simpson (1-D) & 0.139 (Kachadhara) to 0.842 (Siligurijan) & 0.3513 (Mer) to 0.884 (Bildora) \\
\hline
\end{tabular}

from 35 cells $\mathrm{L}^{-1}$ to 3808 cells $\mathrm{L}^{-1}$ from filtered method while $1.55 \times 10^{4}$ cells $\mathrm{L}^{-1}$ to $12.33 \times 10^{5}$ cells $\mathrm{L}^{-1}$ from sedimentation method. The highest number of cells of Chlorophyta, Bacillariophyta and Cyanophyta were recorded in Jaluguti beel, Deepor beel and Mer beel respectively (Table 3 ).

Diversity indices of phytoplankton varied widely by FM and SM at selected beels (Table 4). Dominance index, Richness index, Evenness index, Shannon index and Simpson index were varied from 0.158- 0.861, $0.281-1.717,0.29-0.98$. $0.297-2.031$ and $0.139-0.842$ by FM while $0.116-0.649,0.641-1.652,0.242-0.644$, $0.576-2.448$ and $0.351-0.884$ by SM, respectively (Table 5).

\section{DISCUSSION}

The number of species and density in FM were invariably lesser than SM due to exclusion of minute phytoplankton $(<25 \mu)$ in the FM and higher species number and density recorded in SM were obviously because most of the phytoplankton present in beel water were retained in the samples. Margalef (1969) concluded that only $10 \%$ of all cells retained by nets with a mesh size $40 \mu \mathrm{m}$ and nets with very fine mesh sizes (e.g. 5-10 $\mu \mathrm{m}$ ) catch small cells more effectively than coarse nets. However, a quantitatively important component of the phytoplankton may also pass through modern nets with fine meshes (McCarthy et al., 1974; Durbin et al., 1975). Because of their selective and non- predictable filtering properties, nets cannot be employed in quantitative phytoplankton sampling and it have been developed primarily for quantitative zooplankton sampling. The sedimentation method was first proposed by Volk and it has been widely used in oceanographical studies (Sukhanova, 1981). The advantages of sedimentation method is more retention of cells than filtered method. Chlorophyta was the dominant group by SM and similar observations were made by many researchers in a number of beels such as Dighali beel, Dora beel, Ghorajan beel, Sondora beel, Deepor beel etc. of Assam (Acharjee et al., 1998; Bhuyan et al., 2009; Sharma, 2012, 2015). Sharma (2004) recoded Bacillariophyta as a dominant group followed by Chlorophyta and Cyanophyta in Samuajan beel. The highest number of species recorded in Bildora Beel (18 species by SM) can be attributed to this seasonally open beel getting connected to its adjoining Kulsi River during the southwest monsoon season. Blooms on Anabaena sp. and Microcystis sp and high- est density of Chlorophyta and Cyanophyta were recorded in Mer Beel partly because of application of supplementary feed for rearing of fingerlings in pen enclosure. Chlorophyta grow in waters of a great range of salinity, varying from oligotrophic freshwaters to those that are marine and supersaturated with solutes. Under excessive conditions of nutrient loading (primarily phosphorus), slow moving or stagnant water, and warmth, cyanobacteria may proliferate. Charan beel, which is another seasonally open beel receiving flora from its parent river ( $\mathrm{R}$. Kolong) through a connecting channel (Khanajan) and Siligurijan Beel connected to Brahmaputra River during the monsoon recorded highest second number of species by SM. Least number of species was recorded in Deepor Beel and 46 Morakolong beel indicating that both beels are not properly manage and gradually losing their phytoplankton diversity. The highest number of Bacillariophyta was recorded in Deepor beel due to revival of seasonal connection of the beel with River Brahmaputra during the southwest monsoon season. Deepor Beel is importance beel of NER region and have been declared as a Ramsar site. Euglenoids live in hard or soft water habitats of varied $\mathrm{pH}$ and light levels -mainly marshes, swamps, bogs and other wetlands with an abundance of decaying organic matter. Their populations thrive under high nutrient levels and are, therefore, useful bio-indicators of such conditions. The highest number of Chrysophyta was recorded in Jaluguti beel which was closed beel. They are usually most abundant and diverse in freshwaters of neutral or slightly acidic $\mathrm{pH}$ with low conductivity, alkalinity and nutrient levels as well as colder temperatures.

Lowest value of dominance index (0.158) and highest value of richness index (1.717), Shannon's index (2.031) and Simpson's index (0.842) were recorded in Siligurijan beel while highest value of evenness index (0.980) was recorded in 46 Morakolong beel by FM showed good environmental quality due to seasonally open beels. On other hand, lowest value of dominance index (0.116) and highest value of richness index (1.652), evenness index (0.642), Shannon's index (0.448) and Simpson's index (0.884) were recorded in Bildora beel by SM showed better environmental quality due to seasonally open beel among other beels. Highest number of species (18) recoded in Bildora beel is also indicator of good water environment. During the present study the average Shannon's index was found to be highest in Bildora Beel followed by Silig- 
urijan Beel and minimum in Kachodhara Beel. The value of these indices indicates the species number richness was higher in Bildora Beel followed by that in Siligurijan Beel. The advantage of this index is that it takes in to account the number of species and the evenness of the species. This index is increased either by having additional unique species or by having greater species evenness. It was reportedly heavily infested with floating macrophytes which was cleared by AFDC Ltd, Guwahati, a few years back. Bildora and Siligurijan beels during the monsoon season having oligotrophic tendencies. In the present study, the highest value of Simpson's index was recorded in Bildora Beel (0.884) and Siligurijan Beel (0.842) which suggest greater species diversity in the seasonally open beels. The minimum value recorded in Kachodhara Beel (0.139) and Mer beels (0.351) showed lower species diversity denoting eutrophic condition.

\section{Conclusion}

Quantitative study of phytoplankton by FM and SM were significance difference. Analysis of phytoplankton by FM and SM proved that species diversity as well as species number were more in SM than FM due to maximum retention in SM and exclusion in FM. This research will be helpful for further research in quantitative as well as qualitative study of phytoplankton.

\section{ACKNOWLEDGEMENTS}

I am extremely grateful to Director, ICAR-CIFRI, Barrackpore, Kolkata, India. This work is a part of my professional attachment training of Scientist (on probation), ICAR- CIFRI, Barrackpore. I am thankful to Dr.Dipesh Debnath (scientist), Mr. Pranab Gogoi, Senior Technical Assistant Guwahati regional centre of ICAR-CIFRI for their kind support during sampling period of professional attachment training. I am thankful to Dr. R. K. Manna, Senior Scientist, ICAR- CIFRI, Barrackpore for co-ordinating the training programme and his support.

\section{REFERENCES}

Acharjee, B., Choudhury, M., Dutta, A. and Goswami, U. C. (1998). Productivity and fish yield in the beels of lower Brahmaputra basin. Indian J. Fish. 45 (4): 419- 427.

Bellinger, E. G. and Sigee, D. C. (2010) Freshwater algaeidentification and use as bioindicators. Wiley- Blackwell.

Bhuyan, K. C., Dutta, A. and Kalita, B. (2009). Hydrobiology and fishery status of Sondoba beel, Morigaon, Assam. J. Inland Fish. Soc. India. 41(2): 48-53.

Chandra G. (2011). Management regimes and institutional arrangement in floodplain wetlands fisheries of Assam: An evaluation. Indian J. Extension Education. 47(1\&2):
27-33.

Cox, E. J. (1996). Identification of freshwater diatoms from live material. Chapman \& Hall.

Durbin, E. G., Krawiec, R. W. and Smayda, T. J. (1975). Seasonal studies on the relative importance of different size fractions of phytoplankton in Narragansett bay (USA). Mar. Biol. 32(3): 271-287.

Goswami, M. M. and Gbswami, N. (2001). Studies on productivity indicators in Mori beel of Assam. Trop. Zool. 2\&3: 1-9.

Madhu, N. V., Jyothibabu, R., Balachandran, K. K., Honey, U. K., Martin, G. D., Vijay, J. G., Shiyas, C. A., Gupta, G. V. M. and Achuthankutty, C. T. (2007). Monsoonal impact on planktonic standing stock an abundance in a tropical estuary (Cochin back waters- India). Estuarine, Coastal and Shelf Science. 73 (1-2): 54-64.

Margalef, R. (1969). Counting, In: R. A. Vollenweider, J. F. Talling and D. F. Westlake (eds). A manual on methods for measuring primary production in aquatic environments including a chapter on bacteria, International Biological Programme. Oxford and Edinburgh, London. Blackwell Scient. Publ. (IBP Handbk 12): 7-14.

McCarthy, J. J., Taylor, W. R. and Loftus, M. E. (1974). Significance of nanoplankton in the Chesapeake bay estuary and problem associated with the measurement of nanoplankton productivity. Mar. Biol. 24(1): 7-16.

Park, S. J., Park, B. J. and Rhee, S. K. (2008). Comparative analysis of archaeal 16S rRNA and amoA genes to estimate the abundance and diversity of ammonia-oxidizing archaea in marine sediments. Extremophiles. 12: 605. doi:10.1007/s00792-008-0165-7

Rajeevan, M., Bhate, J., Kale, J. D. and Lal, B. (2006). High resolution daily gridded rainfall data for the Indian region: Analysis of break and active monsoon spells. Current Science. 91 (3): 296-306.

Sarma, D., Dutta, A. and Choudhury, M. (2007). Limnology and fisheries of Urpod Beel, Goalpara, Assam. J. Inland Fish. Soc. India. 39(1): 51-54.

Sharma, B. K. (2004). Phytoplankton communities of a floodplain lake of the Brahmaputra river basin, upper Assam. Journal of the Indian Fisheries Association. 31: 27-35.

Sharma, B. K. (2012), Phytoplankton diversity of a floodplain lake of the Brahmaputra River basin of Assam, north-east India. Indian J. Fish. 59(4): 131-139.

Sharma, B. K. (2015). Phytoplankton diversity of Deepor Beel - a Ramsar site in the floodplain of the Brahmaputra River basin, Assam, north-east India. Indian J. Fish. 62 (1): $33-40$.

Shashi Shekhar, T. R., Kiran, B. R., Puttaiah, E. T., Shivaraj, Y. and Mahadevan, K. M. (2008). Phytoplankton as index of water quality with reference to industrial pollution. Journal of Environmental Biology. 29(2): 233-236.

Sukhanova, I. N. (1981) Settling without the inverted microscope. In Phytoplankton manual. UNESCO. pp 97.

Sultana, H. and Gupta, S. (2009). Phytoplankton diversity and dynamics of Chatla floodplain lake, Barak Valley, Assam, North East India- A seasonal study. Journal of Environmental Biology. 30(6): 1007-1012. 